This is a postprint (final submitted manuscript) version of the following article:

ish, J., Parris, D., \& Troilo, M. (2017). Compound voids and unproductive entrepreneurship: The rise of English Fever in China. Journal of Economic Issues, 51 (1), 163-180. https://doi.org/10.1080/00213624.2017.1287506 
Compound Voids and Unproductive Entrepreneurship: The Rise of English Fever in China

\begin{abstract}
China has emerged as an economic power due, in part, to government policies that opened China to the world and created a modern consumer culture. One of these policies is the advancement of English education, including private providers, which has spawned the phenomenon of "English Fever". We use the unique context of the private English education industry in China to illustrate the concept of "compound (institutional) voids" and their relationship to unproductive entrepreneurship. Our contribution is to untangle some of the complexity relating to institutional relationships and describe how compound voids increase the likelihood of rent-seeking behavior.
\end{abstract}

Keywords: Institutions, regulation, social trust, compound void, unproductive entrepreneurship, China, development, educational policy, English Fever

JEL Classification Codes: L26, O10, H52, 12

China must catch up with the most advanced countries in the world. But how shall we go about it? I believe we have to begin by tackling science and education - Deng Xiaoping August 8, 1977

(China Internet Information Center 2014)

\title{
Introduction
}

All of the People's Republic of China (hereafter "PRC" or "China"), especially urban centers like Shanghai, experienced massive growth and development over the past thirty years. 
Shanghai's total GDP grew to 1.92 trillion RMB in 2011, almost four times what it was just ten years earlier (Shanghai Statistics Bureau 2010), tripling per capita GDP and leading to a sharp increase in disposable income. The growth is creating a new Chinese dream: a high-income job, a well-furnished home, a car or two, financial security, and an outstanding education for their children (Adamson 2002). For many, the key to make the dream a reality is English fluency believed to be 'the' antecedent to improving one's skills and finding a good job (Chang 2008; Clavel 2014; Hessler 2010).

China's government has touted English as a means to help the nation advance, arguing that its mastery is critical to becoming an international competitor (Adamson 2002; Hu 2002a). Consequently, the government as an institution developed English educational polices to build "systems of established and prevalent social rules to structure social interactions" (Hodgson 2006, 2) in order to open China to the world and create a modern consumer culture. As demand for English flourished, it was elevated beyond a language and into an ideology. Today, China has the largest number of English learners in the world (People's Daily 2002). Government policy fueled the rise of "English Fever" into an industry worth $\$ 7.5$ billion (46.3 billion RMB), representing more than 50,000 international and domestically owned language centers (Murphy 2013). Like many industries coming of age in the wake of China's market reforms, English education is evolving as it copes with shifting regulations and fickle consumers. As China rejoined the world in the 1980s, English became a mandatory course for all middle school, high school, and university students and remains so today; English exams must be passed for promotion to the next grade. These exams are embedded throughout the educational system and act as social gate-keeping devices (Clavel 2014; Wang 2007; Cheng 
2008). The mandatory exams reinforce English as a symbolic key for success and a valorized form of cultural capital with exchange value. Learning English in China as a second language is a complex task (Norton and Wu 2001), and governmental regulation could not develop quickly enough to meet the burgeoning demands for English education in a new marketplace (Hu 2002b; Qin 1999). Additionally, the opening of China resulted in a new emphasis on materialism, with possible demotion of collective norms such as social trust.

English Fever created an environment for entrepreneurial private language schools to develop and thrive while also cultivating false advertising, poor business practices and cynicism (Chen 2012). Despite reforms, the training of English teachers has not kept pace with demand in quantity and in quality (Hu 2002b; Norton and Wu 2001). A lack of qualified English teachers combined with large class sizes is a severe constraint; many students still struggle with their language skills (Cheng and Wang 2004; Hu 2002b). After graduation, students, even those trained to teach English (Hu 2002b), seek additional sources to improve their English with the hope of one day fulfilling the promise of a better life, the new Chinese dream. Schools were able to promise anything, and were not held accountable (Kwong 1997). Students found unqualified teachers, and false promises of curriculum that did not deliver. Dissatisfaction grew; however, the answer of how to improve the system to meet students' needs while still maintaining profits and market share remains unanswered (Hu 2002b, 2008, 2009; Wu 2001). The educational inequalities in China have made English a service for those who can pay (Clavel 2014). Similar to the financial reforms in China (Liang 2009), these educational policies resulted in an unequal distribution of wealth and processes fostering inequality of English education. 
Despite being cheated by false marketing and other unethical practices, Chinese consumers are still seeking to gain social status by learning English.

The aim of this article is to illustrate how deficiencies in legal systems, particularly the regulatory function, accompanied by the deterioration of values such as social trust, which could compensate for gaps in formal legal institutions, give rise to a predatory environment fostering destructive entrepreneurship (Baumol 1990) at worst and unproductive entrepreneurship at best. The private English industry in the People's Republic of China exemplifies how bamboozling and rent-seeking undermine what should be a benefit to individual purveyors, consumers, and society as a whole: the expansion of the education system. Building upon the work of North (1990) and Khanna and Palepu (2010), we advance the idea of compound voids: the localized failure of both the initial institution and a compensating institution geared towards a specific purpose (e.g. contracting between parties) necessary for markets to function well. We begin with a review of the pertinent institutional economics literature to develop the ideas of compound voids and unproductive entrepreneurship. We then discuss the context of the private English industry in China and how it illustrates the consequences of compound voids. We close with some thoughts about how this particular scenario came into being along with limitations of our work and suggestions for future research.

\section{Institutions and Entrepreneurship}

\section{Legal institutions and entrepreneurship}

Current and prior academic literature underscore the importance of functioning institutions for entrepreneurship and economic development (Baumol, Litan and Schramm 
2007; Gimmon and Levie 2009; Klein 1988; McDaniel 2003, 2005; Minniti and Levesque 2010; Parris and Mclnnis-Bowers 2014; Warnecke 2013). In recent years particular focus has been paid to these topics in the context of emerging markets, especially China (Kim and Li 2014; Luo Sun and Wang 2011; Schweinberger 2014). It is understood that emerging markets differ from mature economies, particularly with regard to the institutional environment (Khanna and Palepu 2010; Peng 2003). An entrepreneur for the purposes of this paper encompass 'one who owns, launches, manages, and assumes the risks of an economic venture' (Greve and Salaff 2003, 3).

Institutions are commonly defined as the "rules of the game" (North 1990, 3) by which society organizes itself. At a basic level, institutions are important for business in general and entrepreneurship in particular because they reduce expropriation of rents by other actors in an economy (Baumol 1990; Casson 1995; Hodgson 2006; North 1990). Such institutions can be either formal (codified in law) or informal (articulated as the norms, values, and attitudes of a society) (North 1990). Note that North and subsequent institutional economists explain the relationship between formal and informal institutions as a complex, reinforcing, and dynamic skein of rules governing human interaction that evolves; there is no simple dichotomy between the two types.

Because of the role of institutions in preventing expropriation of rents, scholars have paid much attention to the workings of legal systems and their impact on entrepreneurial activity (cf. Kim and Li 2014; Aidis, Estrin and Mickiewicz 2012; Levie and Autio 2011; Troilo 2011). Legal systems encompass separate but related institutions such as property rights, rule of law, enforcement of contracts, and regulation (Aidis et al. 2012; Estrin, Korosteleva and 
Mickiewicz 2009; Johnson, McMillan and Woodruff 2002; Levie and Autio 2011; Troilo 2011; Weingast 1995). One useful distinction for the purposes of this paper is vertical expropriation of rents versus horizontal expropriation of rents (Acemoglu and Johnson 2005), and the institutions designed to prevent them. The state can expropriate rents vertically via taxation, fines, and outright seizure of assets; strong property rights are the antidote (Acemoglu and Johnson 2005; Weingast 1995). Horizontal expropriation occurs via "peer" actors in the economy; strong rule of law ("contracting institutions", in the words of Acemoglu and Johnson) and regulation are the remedies (Acemoglu and Johnson 2005; Tonoyan, Strohmeyer, Habib and Perlitz 2010; Troilo 2011).

The focus here is horizontal expropriation and the role of regulation as the primary deterrent to private English schools bamboozling their customers/pupils. It has been noted in other scholarship that regulatory burden can be a severe impediment to entrepreneurial activity. (cf. Djankov, LaPorta, Lopes-de-Silanes and Shleifer 2002; Demirguc-Kunt, Love and Maksimovic 2006; Klapper, Laeven and Rajan 2006). Here it is the lack of regulation that is a concern, not its excess. We are treating the deleterious effects on consumers in particular and society in general when the regulatory function is weak, as this is less studied compared to the phenomenon of excessive regulation and its impact on firms and entrepreneurs.

\section{Social trust and entrepreneurship}

Trust is a function of economic transactions embedded in social relationships (Granovetter 1985). It can be defined as "the subjective probability with which an agent assesses that another agent or group of agents will perform a particular beneficial action" 
(James 2002, 292). Trust implies vulnerability; "situations in which the risk one takes depends on the performance of another actor" (Coleman 1990, 91). To trust someone is to rely on his/her good faith, while to be trustworthy is to exhibit good faith when others rely on you (James 2002).

Two components comprise the act of trusting: the belief in the trustworthiness of other people and the specific preferences of the one who trusts (Sapienza, Toldra-Simats and Zingales 2013). These preferences include risk aversion (Karlan 2005), reciprocity (Cox 2004), and altruism (Ashraf, Bohnet and Piankov 2006). The first component of trust is the focus of this paper. This belief in the trustworthiness of others might be considered an entrepreneurial attitude such as self-efficacy or confidence (Trevelyan 2009), but it is the macro-environment in which new firm formation occurs as opposed to the micro-level cognitive processes behind trust that concern this study. Trust as a societal belief in the honesty of other actors, i.e. trust as social capital (Coleman 1990; Putnam 1995; Fukuyama1995; April 2008) is critical to entrepreneurship and our story.

Cooperation among economic actors is difficult to sustain when there is a finite game, when there are a large number of players, and when information about the other players is lacking (North 1990). The complexities of interaction in these circumstances give rise to opportunistic behaviour, which increases the costs of transactions. Institutions such as trust can operate as constraints on such behaviour and consequently lower transaction costs (Coase1960; Williamson 1985; Jaffe, Carciente and Zanoni 2007). They can function as intermediaries between the entrepreneur and the sources of inputs (Casson 1995). From the entrepreneur's point of view institutions such as trust serve to decrease the likelihood of 
expropriation of rents from their labour and ingenuity (McMillan and Woodruff 2002), particularly when formal institutions such as rule of law are lacking (Kim and Li 2014; Troilo $2011 ; 2010)$.

\section{Compound voids and unproductive entrepreneurship}

In describing why emerging markets are emerging, Khanna and Palepu (2010) coined the term "institutional void". Where markets lack the needed institutions to bring buyers and sellers together in an efficient manner, a void exists (Khanna and Palepu 2010). Consonant with the literature above, which these authors were also accessing, these voids raise transaction costs and if severe enough can cause markets to collapse entirely.

We draw attention now to the relationship among formal institutions, informal institutions, and entrepreneurial activity with respect to expropriation of rents. Baumol (1990) famously posited that the "rules of the game" could incentivize various kinds of entrepreneurship: productive, unproductive, and destructive. He associates the first with the introduction of new products/services and economic growth via recombination of inputs (Schumpeter 1934) and the second with rent-seeking; curiously, he doesn't clearly delineate between the second and third types (Sauka 2008). Both unproductive and destructive entrepreneurship can involve rentseeking, illegal activities such as the drug trade and smuggling, and licit activity that occurs in the shadow economy; furthermore, firms can engage in various types of entrepreneurial activity simultaneously (Baumol 1990; Sauka 2008).

As discussed above, institutions tend to be mutually reinforcing meta-systems governing human behaviour (Hodgson 2006; North 1990). As economies develop, norms such as trust become codified in regulations and contract law; these laws don't supersede trust so much as 
add another layer of protection against expropriation of rents. In the emerging market context, the relative lack of protection offered by contract law and/or regulations can be compensated by a relatively high level of social trust (Kim and Li 2014; Troilo 2011; 2010)

It seems trivial to say that a lightly regulated or unregulated industry such as private English academies in an emerging market such as China will give rise to predatory behaviour such as swindling the students. If we examine the situation more closely, however, we find there is more than just the failure of the government to regulate or enforce contracts between schools and students; there is also a breakdown in social trust allowing shady English schools to thrive and thereby encouraging new entry into this realm of unproductive entrepreneurship. We advance two propositions for consideration:

Proposition 1: Compound voids are institutional voids characterized by the failure of two similar institutions to reinforce each other and the market in a localized instance.

Proposition 2: While the presence of unproductive entrepreneurship may be due to an institutional void, it is more likely the result of compound voids given the lack of reinforcement inherent in this concept.

Let us examine these two propositions in turn. The first involves what we might term a "primary institution" and a "secondary institution" with regard to protection against horizontal expropriation of rents, i.e. regulation/contract law and social trust. This is what we mean by "similar"; the function/purpose of the two institutions is shared. We may imagine that in most circumstances the "primary institutions" are formal in nature whereas the "secondary institutions" are informal, but this characterization, while generally true, need not be absolute. The presence of the initial void, lack of regulation/contract law, could be compensated if social 
trust is relatively high. Purveyors of English schools would recognize that, although the government may not be doing an adequate job of monitoring their activities, they would be foolish to violate the norm of trust bonding them to their pupils. This is not the case, so there is no effective protection for consumers of English. Lack of mutual reinforcement undermines the market for this service.

The phrase "in a localized instance" merits explanation. Its use demarcates the intellectual space we are identifying in our study of institutions. We are not speaking here of a failed state, or even a dysfunctional one, where the failure of institutions is pervasive. China is far from this condition; indeed its meteoric growth is often hailed as testimony to wise and gradual institutional change in contrast to Iraq or Russia where such change seemingly happened overnight. The "localized" nature of the compound void could be geographic or industry-specific or both; it impacts a given market but not the entire national economy.

The second proposition flows from the first. The presence of an institutional void need not be devastating, though as Khanna and Palepu (2010) note, such voids do present operational challenges. If social trust is present as it should be, the temptation towards unproductive entrepreneurship is less because English providers recognize that there are reputational and real operating costs from violating this norm. Not only do compound voids expose customers to bamboozlement, they also encourage shady characters to enter and open their own "English schools" to victimize the naïve. It is a matter of degree. There is no doubt that some unproductive behaviour would occur in the absence of regulation/contract law, but the compound void exacerbates this tendency greatly. 


\section{English Fever and the Emergence of the Private School Industry in China 1987-2012}

Governmental policies to open China's economy and culture to the world created business markets fostering a culture where English became a symbol of success - the path to the newly formed middle class (Yajun 2003). Over the last 25 years the effects of these policies led to dramatic changes in society, educational development, and the rise of the private education industry. English Fever created an opportunity for entrepreneurs to start private English schools. As China's rise began and people's lives improved, demand grew for products and the creation of new economic opportunities that could help a child perform better in school, especially in English. Over time the private English education market has moved from mass consumption models to a test-taking emphasis and then to Western pedagogical methods for learning oral English by Chinese providers, and finally to international entry.

The Mass Consumption of English

One of the first influential entrepreneurs of the private education market was Li Yang (Yajun 2003). He embodies the market entrepreneur defined by Joseph A. Schumpeter (1943) who creatively innovated through a process of questioning the status quo of existing products and services. Like many Chinese, Li struggled with English and was shy and nervous about the oral component of the College English Test (CET-4). In 1987, as a frustrated student studying English, he suddenly yelled out the words and discovered he could speak the lines more clearly. Li started Crazy English that 'taught' English through yelling. The demand for English fueled the success of Li's mass consumption product where he would yell English together with thousands of English learners filling stadiums throughout China. Before long he had books, tapes, TV shows, and even a film (Yajun 2003). 
Crazy English was the bridge from the older Communist system to the birth of a more market-based and utilitarian English private school industry. Li responded to the insecurity and desperation of consumers to create an empire of products. His method of uniform yelling (chanting) satisfied consumers' psychological needs by helping them to feel confident about English, the new culture, and China's new place in the world. As consumers realized he did not actually teach English the cult of Crazy English began to fade; however, today it remains profitable.

The Test Takers

Another first mover in the private education sector is the New Oriental School. It was founded in 1993, and is now the largest private English school in China traded on the New York Stock Exchange (Osnos 2008; Yajun 2003). Unlike Crazy English, the school focuses on helping students pass the exams that determine their futures. The teaching delivers test-taking strategies, exam analysis, and strategic memorization to pass international tests like the TOEFL, ISLETS, and the GRE as well as local exams like CET4, CET6, and simultaneous translation. Due to the importance of the exams, thousands of imitators popped up across the nation to teach testtaking skills. Before long, university, high school, and even middle school teachers began starting private schools for their students to take additional classes in the evenings and weekends. Teachers of schools with a good record for English-language learning (i.e., valued brands) started private schools using the school's name and classrooms. They adopted testtaking strategies from the New Oriental School and added reviews connected to public schools' curricula. These ventures allowed teachers to make larger salaries, and the owners to become wealthy. Today, test-taking schools are offered throughout almost all levels of education. 
In addition, there is another market of test-taking schools targeting adults who are no longer in school as well as university students seeking to go overseas. They take classes to pass the GRE, TOEFL, IELTS, and GMAT. These companies also have expanded their product offerings to include exam preparation for adult exams offered in the workplace, such as simultaneous translation exams for career translators and English exams for workers aspiring to the hospitality industry. These schools sell textbooks, workbooks, and a variety of other print materials. Given the emphasis on rote memorization throughout China's educational system, these schools have been popular; however, the lack of practical oral English instruction in these centers is a continuing weakness.

\section{The Promise of Western Methods to Improve Oral English Skills}

Throughout the last decade the lack of regulation for training centers in China enabled schools the ability to promise anything without being held accountable and "US education becomes a selling point and an incentive to lie!" (Gao 2013). Students found foreign teachers who were unqualified, and false promises of 'new and quick learning' curriculum that did not deliver. A teacher of TOEFL writing emphasized how "high score guaranteed is just recruiting strategy. As long as students are willing to register, the school will take all" (Li 2012).

Dissatisfaction grew. However, nobody knew how to improve the current system to meet students' needs while still maintaining profits and market share. Students believed English was critical to their success and would keep trying, despite being cheated (Chen 2012).

These observations are supported by ethnographic participant-observation by the first author, who taught English in China for 11 years and kept a reflective journal. To provide credibility (internal validity), we used triangulation by analyzing multiple data sources. 
Transferability (external validity) was achieved by developing a narrative description of the data by the first investigator keeping a reflective journal. In order to improve dependability (reliability) and conformability (objectivity), the second and third authors, who were not involved in data collection, served as auditors and reviewed all analyses and interpretations (Lincoln and Guba 1985).

By 2002, schools that claimed to use Western teaching methods, have smaller class sizes, and develop oral English skills began to open. Smaller classes sizes allowed schools to claim higher quality, as well as, charge higher prices. See Figure 12002 Shanghai English Center Tuition \& Class Size based on marketing research conducted by the first author.

Figure 1: 2002 Shanghai English Center Tuition \& Class Size

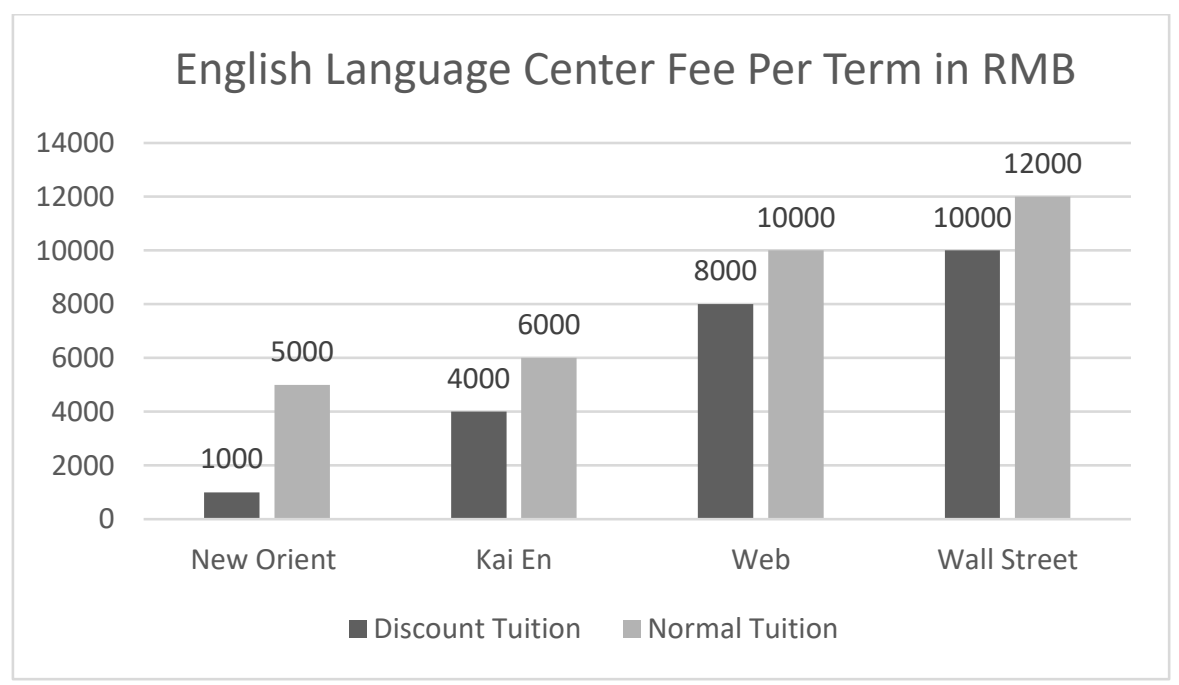




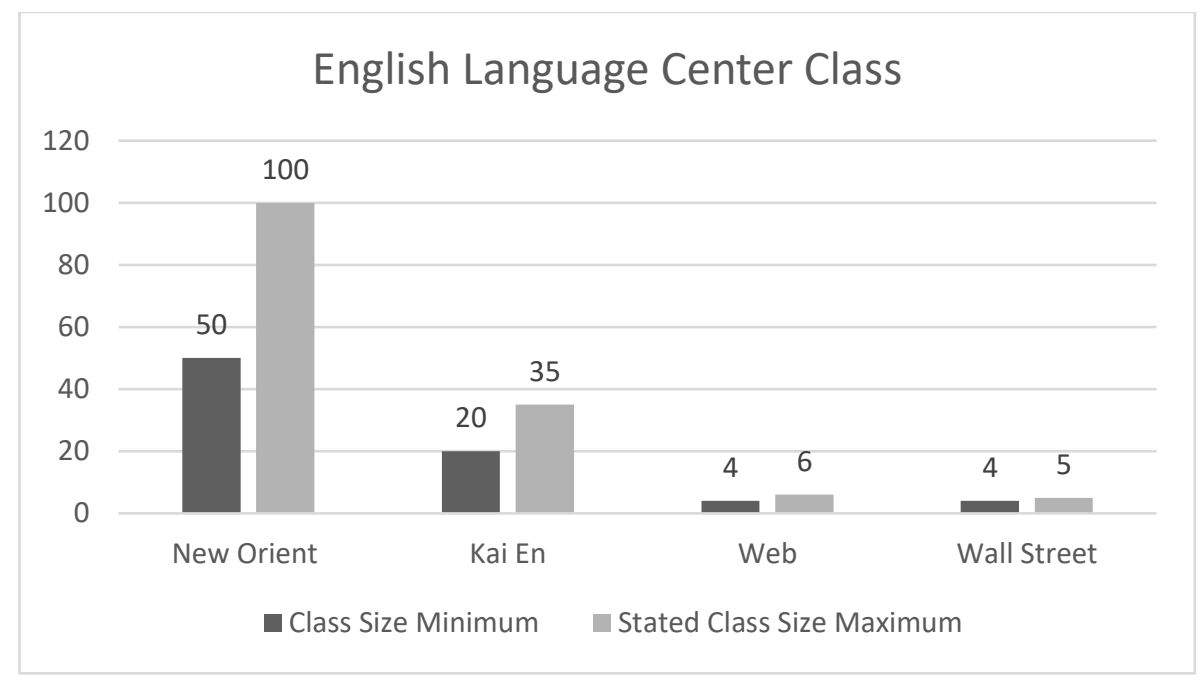

Advertising foreign teachers and smaller class sizes was a successful marketing method and also enabled schools to charger a higher price; however, the schools could not find teachers that could use these new interactive methods. The shortage of teachers, along with consumers' lack of knowledge of these new methods or understanding what type of program would satisfy their needs, resulted in this niche market being one of the most fluid and broad parts of the private education system. For example, some schools, such as ONLY in Shanghai, adapted the teaching methods of public schools and decreased class sizes to do more oral exercises in class. They created oral textbooks that focus on speaking and listening; nevertheless, they still taught in the traditional manner - from the text. On the other side, some schools opened that were set up as social meeting places to discuss business, current events, or whatever else interested the students. No matter the school, one of the biggest draws was the chance to interact with foreign teachers.

Although universities recruited English teachers throughout the 1980s and 90s, the number of foreign teachers was small. As university professors and schools opened up private 
schools on campus, they began inviting foreign teachers to give talks and eventually teach in their schools. A valuable marketing tool for these schools was providing access to native speakers. Private schools offered much larger salaries to foreign teachers than the public schools. They could not meet demand, which sparked the growth of headhunting companies to bring Westerners to China. The quality and background of these foreign teachers varied with "some foreign teachers come from India or Malaysia. They have a strong accent - not standard British or America English. Others are just foreign students from nearby universities without any training (Beijing Daily 2011). Many had little or no training as a teacher; however, the marketing benefit of having native speakers far outweighed the lack of teaching ability and became an essential selling point. Even though governmental approval was required to hire foreigners, schools often ignored this requirement. The promise of "foreign teachers is just a formula" and for most institutions "it's all a fraud" (Beijing Daily 2011). The schools promoting smaller class sizes and Western methods needed foreign teachers in their marketing materials to thrive.

International Companies Enter the Market

As foreign teachers spent time in China, they saw the potential for greater rewards by opening up their own schools. The market was booming and many joint-venture schools popped up overnight at the turn of the millennium. Some of these were small ventures in which the foreign teacher was freelancing while others became quite large. For instance, Kai En in Shanghai was started by an Irish foreign teacher who lived in Shanghai for years; it eventually grew into a school with more than 20 locations and hundreds of employees. In addition, international English training companies started selling franchises or setting up expatriate-led 
ventures in China. The most famous of these, EF, already had a global presence. EF promised smaller class sizes and Western pedagogy. Their success spawned a franchise-based jointventure structure, but a number of the franchisees compromised the brand name by cutting corners on educational quality.

By 2002, wholly owned foreign enterprises (WOFEs) like Wall Street and Web International moved into the market providing higher-end services to big-city elite. Wall Street fosters an upscale, professional image with all of its foreign teachers dressed in suits. They were among the first schools to use only foreign teachers and they promised very small class sizes. Foreign teachers are scarce, expensive, and of unknown quality. These new schools needed to find a way to make the venture profitable. Their solution was an internal computer-based curriculum that students need to complete to earn time with the foreign teacher-for every ten hours of online study students interact with the foreign instructor for an hour. However, advertised promises were frequently not meant or complaints of poor quality also were not acknowledge. A prototypical consumer experience as student is told by a student a Wall Street: [They] promised foreign teachers... I've studied for two units and so far the amount of classes provided with foreign teachers are quite limited. Besides, reservation for those = limited classes is extremely difficult, let alone catering to my schedule. What's more annoying is that all the teacher taught were grammar and simple sentences, as well as = making us listen to tapes repeatedly.... I Feel I have been tricked and cheated, I applied to drop out school and returning the rest of my money, but Wall Street English brutally refused (Wang 2009).

Many students repeatedly were cheated and tricked by advertised promises (Chen 2012). 
If a school appeared profitable bring schools other schools would open copying the business model and marketing for instance: "the New Oriental ISAY program in Wuhan is a complete copy from New Dynamic, Web, E-bar and EF" (Zhang 2012). Web developed a similar computer-based curriculum copying Wall Street but with a more 'Silicon Valley' culture. Teachers are younger and dress more casually, like the image of Steve Jobs, but the company operates in the same fashion as Wall Street. Through heavy marketing as an upscale alternative, they are able to charge high prices. Wall Street charges 10,000 RBM per class, in comparison this is equivalent to a year at university, and for perspective it would take a Chinese family living on the poverty line more than 60 years of per capita income to pay for four years of college (Chen 2012). This pricing/brand strategy became more lucrative as class sizes decreased and the supply of native English instructors increased. However, the promise of foreign teachers, and having actual instruction by them was frequently broken. As highlighted by Ming Li "there is no way to have so many well-known teachers if you don't use advertising tricks. To tell you the truth, we have no highly qualified teachers, just several ordinary foreigners with nice suits who had their photos taken and framed on a big advertising board then placed in a busy street to attract attention and gain trust" (Li 2012). These two players survived the inevitable winnowing that occurs when a new industry matures.

Accompanying Niche Markets

As the English-language industry developed and grew, niches formed. Schools started to cater to business English, English for academic purposes, and/or other specialized courses, such as teaching English in hospitality trades or to medical workers. As the Olympics came to Beijing 
there were programs developed to teach English to taxi drivers and polite conversation to the hordes of volunteers. If there was a perceived need, programs and new ventures developed.

As English Fever continued, the first generation of adults who had gone through the new education system demanded English education at an earlier age for their children. To meet this need, English-focused nursery schools and kindergartens mushroomed. Since there were no public schools in this niche, private kindergartens started first. Many focused on English education and Western pedagogy, thereby continuing the tradition of wanting foreign teacher involvement. Qualified Chinese instructors taught the majority of the English curriculum while foreign teachers taught only specialized lessons a few times each week. Parents were willing to pay more for contact with foreign teachers; higher-priced schools contracted full time foreign teachers to meet the demand. Saturday classes also developed with foreign teachers to satisfy parents who could not afford the Monday through Friday foreign-instructor-only classes. Kindergartens and primary afterschool private language schools often were one venture so students could take classes at the same location for years.

Pre-schools entered the market next. Many were extensions of the kindergartens linked to public schools while some were independent and located in shopping malls for convenience to parents. These schools offered babysitting services combined with English classes. In 2008, Disney entered China's English education market targeting students aged two to twelve. Disney marketing research revealed that for Chinese parents 'education means everything' (and) ...English is viewed as a ticket to the wider world" (The Economist 2010). These centers provide contact with foreigners as well as Disney culture. Not only are the students connected to a lifelong study of English, but also consumerism as DVDs, stuffed toys and all sorts of Disney 
products are available. The expansion of private English education reaches consumers at all stages and aspects of their lives.

\section{Weaknesses in Private Education}

There is essentially no regulation of the private education sector. Schools are able to promise anything and are not held accountable (Kwong, 1997). Dissatisfied students have no government agency to receive their complaints. Although students will complain online, the marketing campaigns of the schools often drown out their voices.

Schools are able to lie about teachers' qualifications with impunity (Edkins 2012). Foreign teachers are a valuable commodity and a visible resource that schools use for advertising. According to one of the co-authors, who spent nine years in China's education sector, schools tout the teaching credentials of their instructors, yet few of the foreigners really have teaching experience. Many are young people seeking adventures, having recently graduated from school themselves or bouncing from one job to the next without even a degree in their home country. For instance, truck drivers with a high school diploma were marketed as college professors with years of English-language teaching under their belts. Sometimes this occurs without the foreigner even being aware of the deception. Deception is prevalent in other ways. Curriculum and language resources were marketed as being developed in the West when they were either internal materials cobbled from a variety of sources or just a Chinese textbook reformatted as the school's own resource. Often, China's own copyright laws were violated in sourcing these documents. Students were promised a small class size only to see class's double during the semester as new students were added. Often the school made conditions bad for the students who already paid just so they would leave the program and open up seats for new students. 
Schools just vanished when the leases ran out, taking all the tuition and even the staff's pay with them.

The schools' ability to do this is exacerbated by a customer base that has little understanding of what they really want and "those who don't understand are easily cheated and tricked by all sorts of advertisements" (Zhang 2012). They found foreign teachers who were unqualified and inept. They relied on promises of new curriculum but did not have the language skills to see that the materials were substandard. Parents with limited English skills bought into the promises and blamed the students for poor progress. Dissatisfaction is growing but policing the system requires resources. This 'Wild West' market of English education in China highlights that not all types of entrepreneurial activity are correlated with improved wellbeing (Warnecke, 2013). Students believe so strongly that English is key to their success that they keep trying, facing disappointment after disappointment as they continue to be bamboozled in new ways. It seems as if the schools are always one step ahead of the students.

\section{Discussion and Conclusion}

Private English schools exemplify the development of an industry without at least several key institutional supports: effective regulation, enforcement of contracts between students and schools, and the norm of social trust. For this last institution, we offer some evidence from the World Values Survey (WVS) on Table 1. China was not included in the initial wave from 1981-1984 but did participate in the five subsequent waves.

Table 1: Changes in Trust over Time in the People's Republic of China

\begin{tabular}{|l|l|l|}
\hline Wave & Time & TrustYes \\
\hline 2 & $1989-1993$ & $59.40 \%$ \\
\hline
\end{tabular}




\begin{tabular}{|l|l|l|}
\hline 3 & $1994-1998$ & $50.40 \%$ \\
\hline 4 & $1999-2004$ & $52.50 \%$ \\
\hline 5 & $2005-2009$ & $48.67 \%$ \\
\hline 6 & $2010-2014$ & $61.52 \%$ \\
\hline
\end{tabular}

The TrustYes variable is a categorical variable familiar in the social trust literature (cf.

Sapienza, Toldra-Simats, and Zingales 2013) where the question, “Do you think most people can be trusted, or that you can't be too careful" (WVS 2014) is posed to survey respondents; TrustYes is the percentage affirming that most people can be trusted. One notes that for the duration of the development of private English schools in China examined here (1987-2010), the level of social trust in China diminishes steadily, though it does rebound in the sixth wave (2010-2014). This trend is suggestive though hardly conclusive of the erosion of a key informal institution; a thorough empirical investigation is needed.

There is more circumstantial evidence. The development of the private English industry in the PRC is most pronounced in the cities, which by nature is more impersonal than country living. The combination of steady urbanization as well as the emphasis on material well-being exemplified by slogans such as "It is glorious to get rich" may be undermining social trust. Table 2 contains some data about which values are most important to people, again from the WVS.

Table 2: Changes in Values over Time in the People's Republic of China

\begin{tabular}{|c|c|c|c|c|c|c|}
\hline Wave & Time & $\begin{array}{c}\text { Maintain } \\
\text { order }\end{array}$ & $\begin{array}{c}\text { Give people } \\
\text { more say }\end{array}$ & $\begin{array}{c}\text { Fight } \\
\text { inflation }\end{array}$ & $\begin{array}{c}\text { Freedom of } \\
\text { speech }\end{array}$ & No answer \\
\hline 2 & $1989-1993$ & $66.20 \%$ & $14.00 \%$ & $16.70 \%$ & $2.60 \%$ & $0.50 \%$ \\
\hline
\end{tabular}




\begin{tabular}{|c|c|c|c|c|c|c|}
\hline 3 & $1994-1998$ & $69.20 \%$ & $5.87 \%$ & $22.00 \%$ & $0.00 \%$ & $2.93 \%$ \\
\hline 4 & $1999-2004$ & $49.70 \%$ & $10.10 \%$ & $23.10 \%$ & $4.40 \%$ & $12.70 \%$ \\
\hline 5 & $2005-2009$ & $34.76 \%$ & $11.00 \%$ & $26.02 \%$ & $3.82 \%$ & $24.40 \%$ \\
\hline 6 & $2010-2014$ & $27.91 \%$ & $9.48 \%$ & $50.22 \%$ & $2.61 \%$ & $9.78 \%$ \\
\hline
\end{tabular}

The percentages sum to $100 \%$, so larger percentages indicate that a given value is relatively more important than the others. Among the choices offered, the first "Maintain order in the country", may be characterized as more collectivist in nature, while "Give people more say", "Fight rising prices (inflation)", and "Protect freedom of speech" are oriented towards individual concerns. The PRC, relative to most countries, is still collectivist in outlook, but there has been a shift since the opening to the outside world. The assent for maintaining order has declined precipitously from $66.20 \%$ to $27.91 \%$ over the five waves, while the importance of fighting inflation and thereby protecting people's assets has increased sharply over the same time period. This shift in values does not itself constitute an institutional void; however, the increased concern with one's financial status could give rise to a void of trust. We remark again that this is plausible, but not proven. Also noteworthy is that economic stability eclipses the two values associated with political freedoms/impact.

Our purpose is to advance the notion of a compound void as a concept, and to demonstrate its connection with unproductive entrepreneurship. While institutional voids may be troublesome and spur some unproductive entrepreneurship, institutional economic theory (North 1990; Baumol 1990) indicates that a given void can be overcome if other available 
institutions, usually but not exclusively informal institutions, are hardy enough to compensate. When the first, formal layer is compromised (lack of regulation, contractual law), a norm such as social trust can dissuade bamboozlement. Both the formal and informal institutions in this case guard against horizontal expropriation of rents, and normally reinforce one another. If both fail, then conditions are ripe for unproductive entrepreneurship. We emphasize that the compound void is a local condition with respect to geography and/or industry segment; it is different from the pervasive collapse of institutions endemic to failed states.

The phenomenon of English Fever in China exemplifies compound voids; studying its evolution led to this concept and the accompanying propositions. China's English Fever is an attempt by the private sector to meet burgeoning demand in English instruction in a rapidly changing socio-economic environment. According to Khanna and Palepu (2010), it is not uncommon to witness institutional voids in such contexts. The fact that formal institutions such as regulations and contract law have not kept pace with developments in private English education in China is hardly surprising.

What is interesting is that the social norm of trust seems to have failed in this instance as well. Trust should be a mitigating factor against the abuses of English Fever; institutional theory indicates that norms and laws are mutually reinforcing and that the former can serve as a deterrent to predatory or rent-seeking behavior in the absence of the latter, at least to a certain extent and for a short duration. Our study of English Fever reveals widespread bamboozlement, and our review of pertinent statistics highlights an ebb in societal trust and the collective good. On the other hand, China's institutions are basically sound; as evidenced by its booming economy over the past three decades. These factors led us to conceive 
compound voids as the failure of similar institutions in a localized instance. Looking at the damage wrought by the abuses associated with English Fever, we further theorized that unproductive entrepreneurship is the result of these compound voids.

Precisely because institutions are complex, interlocking meta-systems of rules that govern human behavior (North 1990; Hodgson 2006), we contribute to this literature by theorizing how the absence of specific institutions impacts economic growth and development. While institutional voids are problematic, the real issues occur when mutually reinforcing, dyadic institutions such as regulation and social trust give way. We propose that the effect of the compound void is a dramatic increase in rent-seeking behavior as opposed to productive entrepreneurship. While other scholarship, most notably Baumol (1990) traces the effects of failing institutions on entrepreneurship and economic development, we offer nuance by circumscribing such failure at a local level as opposed to the level of the nation-state.

There are limitations to our work. Conceptually, we have identified the dyad of regulation and social trust in our discussion of compound voids; certainly there are others of importance. We have not even attempted the measurement of compound voids or what their impact upon unproductive entrepreneurship might be. These metrics must be developed in order to know the scope of the problem and what potential policy solutions might be. It is our hope that this paper will generate interest in these questions for future research. 


\section{References}

Acemoglu, D. and S. Johnson. "Unbundling Institutions." Journal of Political Economy 113, (2005):949-995.

Adamson, Bob "Barbarian as a Foreign Language: English in China's Schools." World Englishes 21,2 (2002) 231-243.

Adamson, Bob. China's English a History of English in Chinese Education. Hong Kong University Press, HK. 2004.

Aidis, R., Estrin, S., Mickiewicz, T. Size Matters: Entrepreneurial Entry and Government. Small Business Economics 39 (2012): 119-139.

AmCham Shanghai.Education \& Training. 2013. Available at http://www.amcham-shanghai.org. Accessed August 18, 2013.

April, W. “Experiential Learning from the Khoi-Khoi (Namibia) and Maori (New Zealand) Communities', International Journal of Entrepreneurship and Innovation, 9, 2 (2008): 103-110.

Areddy, James T. and Peter Sanders. "Chinese Learn English the Disney Way," Wall Street Journal, April 20, 2009. Available at http://online.wsj.com/article/SB124017964526732863.html. Accessed August 25, 2013.

Ashraf, N., Bohnet, I., and N. Piankov. "Decomposing trust and trustworthiness." Experimental Economics, 9, 3 (2006): 193-208.

Baumol, William. "Entrepreneurship: Productive, unproductive, and destructive." Journal of Political Economy 98(5) (1990): 893-921. 
Baumol, William, Robert Litan and Carl Schramm. "Sustaining entrepreneurial capitalism." Capitalism and Society 2 (2007): 1-38.

Beijing Daily. “300 Million Students Leads to English Training Disorder." April 4, 2011. Available at: http://www.bjd.com.cn/10zdtj/201104/t20110406 669270.html Accessed on May 10, 2013.

Boshier, Roger, Yan Huang, Qihui Song and Lei Song. "Market Socialism Meets the Lost Generation: Motivational Orientations of Adult Learners in Shanghai." Adult Education Quarterly 56, 3 (2006): 201-222.

Casson, Mark. Entrepreneurship and business culture, Brookfield, MA Edward Elgar Publishing. 1995.

Chang, Leslie T. Factory Girls: From Village to City in a Changing China. New York: Doubleday Publishing Group. 2008.

Cheng, Liying and Hong Wang. "Understanding Professional Challenges Faced by Chinese Teachers of English." TESL-EJ 7, 4(2004): 1-14.

Chen, Shaohua and Martin Ravallion. "The Developing World is Poorer than We Thought, but No Less Successful in the Fight against Poverty." The Quarterly Journal of Economics 125, 4 (2010): 1577-1625.

Chen, Weijun. "Education, Education". 2012. Available at http://www.whypoverty.net/video/education-education/. Accessed on July 30, 2015. 
China Internet Information Center. "Some Comments on Work in Science and Education" Deng Xiaoping Speech at a Form on August 8, 1977. Available at http://www.china.org.cn/english/features/dengxiaoping/103391.htm. Accessed May 9, 2014.

Clavel, Teru. "China, South Korea Face Familiar Woes in English Quest” Japan Times, January 19, 2014. Available at http://www.japantimes.co.jp/community/2014/01/19/issues/chinasouth-korea-face familiar-woes-in-english-quest/\#.U3JTAyisTu1. Accessed May 13, 2014.

Coleman, James. Foundations of Social Theory Cambridge, MA. Harvard University Press. 1990. Coase, Ronald Harry. "The Problem of Social Cost." Journal of Law and Economics, 3, 1 (1960): 1-44.

Cox, James. "How to identify trust and reciprocity." Games and Economic Behavior 46, (2004): 260-281.

Demirguc-Kunt, Asli, Inessa Love and Vojislav Maksimovic. "Business Environment and the Incorporation Decision." Journal of Banking and Finance 30, (2006): 2967-2993.

Dewey, John. Human Nature and Conduct: An Introduction to Social Psychology. New York: Holt, 1922.

Dillon, Sam. "Top Test Scores From Shanghai Stun Educators” New York Times, December 7, 2010. Available at www.nytimes.com/2010/12/07/education/07education.html?pagewanted=all\& $r$ $=0 \quad$ Accessed June 30, 2013. 
Djankov, Simeon, Rafael La Porta, Florencio Lopez-de-Silanes and Andrei Shleifer. "The Regulation of Entry." Quarterly Journal of Economics 117, (2002): 1-37.

Dow, Tsung I. "The Impact of Chinese Students Returned from America. With Emphasis on the Chinese Revolution, 1911-1949." 1971.

Dugger, William. “Against Inequality.” Journal of Economic Issues 32, 3 (1998): 287-303.

Dulwich College. "Fees" Available at http://www.dulwich-shanghai.cn. Accessed August 18, 2013.

Economist. “Middle Kingdom Meets Magic Kingdom.” August 26, 2010. Available at http://www.economist.com/node/16889262. Accessed on Aug 18, 2013.

Estrin, S., Korosteleva, J., and T. Mickiewicz. Better Means More: Property Rights and HighGrowth Aspiration Entrepreneurship. IZA Working Paper 4396. (2009) Bonn.

Feng, Anwei. "English in China: Convergence and divergence in policy and practice," AILA Review, 22 (2009): 85-102.

Fowler, Aubrey R., Jie Gao and Les Carlson. "Public Policy and the Changing Chinese Family in Contemporary China: The Past and Present as Prologue for the Future." Journal of Macromarketing 30, 4 (2010): 342-353.

Fukuyama, F. Trust. New York, NY. Free Press. 1995.

Gao, Jin. "In China, US education becomes a selling point and an incentive to lie." Ministry of Tofu. January 27, 2011. Available at: http://www.ministryoftofu.com/2010/12/in-china u-s-education-becomes-a-selling-point-and-an-incentive-to-lie/ Accessed on My 1, 2013.

Gimmon, Eli and Jonathan Levie. "Instrumental Value Theory and the Human Capital of Entrepreneurs." Journal of Economic Issues 43, 3 (2009): 715-732. 
Greve, Arent, and Salaff, Janet W. "Social Networks and Entrepreneurship." Entrepreneurship Theory \& Practice 28, 1 (2003): 1-22

Granovetter, M. “Economic Action and Social Structure: A Theory of Embeddedness." American Journal of Sociology, 91, 3 (1985): 481-510.

Hannum, Emily C., Behrman, Jere, Wang, Meiyan and Liu, Jihong. Education in the reform era. Impact of English as Global Language Asia-Pacific Region. 2008.

Hertling, James. "Chinese Students Embrace the English Language" Chronicle of Higher Education January 5, 1996. Available at http://chronicle.com. Accessed on July 23, 2013. Hessler, Peter. Country Driving: A Chinese Road Trip. New York: HarperCollins Publishers. 2010. Hsü, Immanuel. The Rise of Modern China. Oxford: Oxford University Press. 1990. Hodgson, Geoffrey M and Kainan Huang. "Brakes on Chinese Development: Institutional Causes of a Growth Slowdown." Journal of Economic Issues 47, 3 (2013): 599-622.

Hodgson, Geoffrey M. "What are Institutions?" Journal of Economic Issues 40, 1 (2006): 1-25. Hu, Guangwei. "Recent Important Developments in Secondary English-language Teaching in the People's Republic of China, Language." Culture and Curriculum 15, 1 (2002): 30-49. Hu, Guangwei. “English Language Teaching in the People's Republic of China." English language education in China, Japan, and Singapore (2002): 1-77.

Hu, Guangwei. "English Language Education in China: Policies, Progress, and Problems." Language Policy 4, 1 (2005): 5-24.

Hu, Guangwei. "The Misleading Academic Discourse on Chinese-English Bilingual Education in China." Review of Educational Research 78, 2 (2008): 195-231. 
Hu, Guangwei. "The Craze for English-medium Education in China: Driving Forces and Looming Consequences." English Today 25, 4 (2009): 47-54.

Hu, Huiting. "Family Planning Law and China's Birth Control Situation." China.org.cn October 18, 2002. Available at http://www.china.org.cn/english/2002/Oct/46138.htm]. Accessed August 15, 2013.

Hu, Yuanyuan. “China's Foreign Language Policy on Primary English Education: What's Behind It?" Language Policy 6 (2007): 359-376.

IndexMundi. "China - Education Expenditure." Index Mundi. 2013. Available at http://www.indexmundi.com/. Accessed June 28, 2013.

Jaffe, Klaus, Sary Levy Carciente and Wladimir Zanoni. "The Economic Limits of Trust: The Case of a Latin-American Urban Informal Commerce Sector." Journal of Developmental Entrepreneurship, 12, 3(2007): 339-352.

James, Harvey. "The Trust Paradox: A Survey of Economic Inquiries into the Nature of Trust and Trustworthiness." Journal of Economic Behaviour \& Organization 47 (2002): 291-307. James, William. Psychology: Briefer Course. New York and London: Holt and Macmillan, 1892. Joas, Hans. Pragmatism and Social Theory. Chicago: University of Chicago Press, 1993. - - . The Creativity of Action. Chicago: University of Chicago Press, 1996. Johnson, Simon, John McMillan, and Christopher Woodruff. Property Rights and Finance. American Economic Review 92 (2002): 1335-1356.

Karlan, Dean. "Using Experimental Economics to Measure Social Capital and Predict Financial Decisions." American Economic Review 95, 5 (2005): 1688-1699. Keenan, Barry. The Dewey Experiment in China: Educational Reform and Political Power in the 
Early Republic. Cambridge, Mass: Harvard University Press. 1977.

Khanna, Tarun and KrishnaPalepu. Winning in Emerging Markets: A Road Map for Strategy and Execution. Cambridge, Mass: Harvard Business Press. 2010.

Kilpinen, Erkki. The Enormous Fly-Wheel of Society: Pragmatism's Habitual Conception of Action and Social Theory. Helsinki: University of Helsinki, 2000.

Kim, Phillip H. and Mingxiang Li. "Seeking Assurances when Taking Action: Legal Systems, Social Trust, and Starting Businesses in Emerging Economies." Organization Studies 35, 3 (2014): 359-391.

Klapper, Leora, Luc Laeven and Raghuram Rajan. “Entry Regulation as a Barrier to Entrepreneurship." Journal of Financial Economics 82, (2006): 591-629.

Klein, Philip A. "Changing Perspectives on the Factors of Production." Journal of Economic Issues 22, 3 (1988): 795-809.

Kwong, Julia. "The Reemergence of Private Schools in Socialist China." Comparative Education Review 41, 3 (1997): 244-259.

Lague, David. “1977 Exam Opened Escape Route into China's Elite." New York Times. January 6, 2008. Available at http://www.nytimes.com. Accessed June 30, 2013.

Lam, Agnes. "English in Education in China: Policy Changes and Learners' Experiences." World Englishes 21, 2 (2002): 245-256.

Levie, Jonathan. and Erkko Autio. "Regulatory Burden, Rule of Law, and Entry of Strategic Entrepreneurs: An International Panel Study." Journal of Management Studies 48, (2011):1392-1419. 
Liang, Yan. "Financial Reform, Property Income Growth and the Potential Impacts on Inequality in China." Journal of Economic Issues 43, 2 (2009): 389-401.

Li, Ming. "Training Tricks Are Everywhere: Investigation of Hangzhou English Training Mess." Hangzhou Discussion Hall. August 20, 2012. Accessed online at http://hwyst.hangzhou.com.cn/mtld/content/2012-08/20/content 4343136 3.htm 2015.

Lincoln, Yvonna S., and Guba, Egon. Naturalistic Inquiry. New York, NY: Sage. 1885

Liu, Zhiqiang. "Institution and Inequality: The Hukou System in China." Journal of Comparative Economics 33 (2005): 133-157.

Luo, Zi-ping. A Generation Lost: China under the Cultural Revolution. New York: Henry Holt \& Co. 1990.

McDaniel, Bruce A. "Institutional Destruction of Entrepreneurship through Capitalist Transformation." Journal of Economic Issues 37, 2 (2003): 495-501.

- - - "A Contemporary View of Joseph A. Schumpeter's Theory of the Entrepreneur." Journal of Economic Issues 39, 2 (2005): 485-489.

McMillan, John and Christopher Woodruff. "The Central Role of Entrepreneurs in Transition Economies." Journal of Economic Perspectives, 16, 3 (2002): 153-170.

Minniti, Maria and Moren Levesque, M. "Entrepreneurial types and economic growth." Journal of Business Venturing 25 (2010): 305-314. 
Murphy, Colin. "English May Be Losing Its Luster in China." Wall Street Journal, November 7, 2013. Available at http://blogs.wsi.com/chinarealtime/2013/11/07/learning english may-be-losing-its-luster-in-china/Accessed May 12, 2014.

Murphy, Rachel. "Turning Peasants into Modern Chinese Citizens: "Population Quality" Discourse, Demographic Transition and Primary Education." The China Quarterly 177 (2004): 1-20.

Naughton, Barry. The Chinese Economy: Transitions and Growth. Cambridge, MA: Massachusetts Institute of Technology, 2007.

North, Douglass. Institutions, institutional change, and economic performance, Cambridge, Harvard University Press. 1990.

Norton, Bonny and Yi'an Wu. "TESOL in China: Current Challenges." TESOL Quarterly 35, 1 (2001): 191-194.

OECD. "How Many Students are in Each Classroom?" Available at http://www.oecd-ilibrary.org. Accessed August 15, 2013.

Osnos, Evan. "Letter from China: Crazy English." The New Yorker April 28, 2008. Available at http://www.newyorker.com/reporting/2008/04/28/080428fa fact osnos. Accessed June 24, 2013.

Parris, Denise and Cecilia McInnis-Bowers. "Social Entrepreneurship Questioning the Status Quo: Waste as a Resource." Journal of Economic Issues 48, 2 (2014).

Pepper, Suzanne. Radicalism and Education Reform in 20th-Centry China. Cambridge: Cambridge University Press, 1996.

People's Daily. "Carry Out the Policy of Opening to the Outside World and Learn 
Advanced Science and Technology from Other Countries." October 10, 1978.

Available at http://english.peopledaily.com.cn/dengxp/vol2/text/b1240.html. Accessed August 15, 2013.

People's Daily. “We Can Develop A Market Economy Under Socialism." November 26, 1979.

Available at http://english.peopledaily.com.cn/dengxp/vol2/text/b1370.html]. Accessed June 27, 2013.

People's Daily. “China Becomes Biggest Market for English Learning.” September 27, 2002.

Available at http://english.peopledaily.com.cn/200209/27/eng20020927 103980.shtml. Accessed June 27, 2013.

Putnam, Robert. “Bowling Alone: America's Declining Social Capital.” Journal of Democracy, 6, 1 (1995): 65-78.

Qin, Jianjun. "The status quo of FLT at tertiary level," Foreign Language Teaching and Research 117 (1999): 3-6.

Rein, Shaun. “China Needs American Education. Here's How to Bring It There." 2012. Available at http://www.forbes.com. Accessed August 18, 2013.

SAIS. “About the Hopkins Nanjing Center." 2013. Available at http://www.sais-jhu.edu. Accessed August 18, 2013.

Sapienza, Paola, Anna Toldra-Simats, and Luigi Zingales. "Understanding Trust". The Economic Journal 123, 573 (2013): 1313-1332.

Sauka, Arnis. "Productive, Unproductive, and Destructive Entrepreneurship: A Theoretical and Empirical Exploration." William Davidson Institute Working Paper \#917, Ann Arbor, MI. 2008. 
Schumpeter, Joseph A. The Theory of Economic Development. Cambridge, MA: Harvard University Press, 1934.

Schweinberger, Albert. "State Capitalism, Entrepreneurship, and Networks: China's Rise to a Superpower." Journal of Economic Issues 48, 1 (2014): 169-179.

Shanghai Statistics Bureau. "Growth Rate of Major Economic Indicators over Preceding Years." 2010. Available at http://www.statssh.gov.cn/tjnj/nje11.htm?d1=2011tjnje/E0109.htm]. Accessed June 29, 2013.

State Statistics Bureau. "Statistics Communiqué of Development of Education in China." China's Social Statistics Year Book 2007. 2007. Beijing: Statistics Publishing House. Su, Zhixin. "A Critical Evaluation of John Dewey's Influence on Chinese Education."

American Journal of Education 103, 3 (1995): 302-325.

Tonoyan, Vartuhi, Robert Strohmeyer, Mohsin Habib, and Manfred Perlitz. "Corruption and Entrepreneurship: How Formal and Informal Institutions Shape Small Firm Behavior in Transition and Mature Market Economies." Entrepreneurship Theory \& Practice 34, (2010): 803-831.

Trevelyan, Rose. "Entrepreneurial Attitudes and Action in New Venture Development." International Journal of Entrepreneurship and Innovation, 10, 1 (2009): 21-32.

Troilo, Mike. "The Role of Trust in New SME Creation: Motivations and Opportunities". International Journal of Entrepreneurship and Innovation 11, 2 (2010): 129-139.

Troilo, Mike. "Legal Institutions and High-Growth-Aspiration Entrepreneurship." Economic Systems 35, 2 (2011):158-175.

Tsang, Mun C. "The Financial Reform of Basic Education in China." Economics of Education 
Review 15, 4(1996): 423-444.

Tsang, Mun C. "Education and National Development in China since 1949: Oscillating Policies and Enduring Dilemmas." China review 2000, 579-618. 2000.

Veblen, Thorstein B. The Theory of the Leisure Class: An Economic Study in the Evolution of Institutions. New York: Macmillan, 1899.

Wang, Junju. "The College English Test in China: challenges and suggestions." Asian Journal of English Language Teaching 17 (2007): 137-144.

Wang, You Cheng. “Disgusting Wall Street English Training Center, My Deceived Experience, To Prevent Others From Being Cheated." Kaixin001 (Chinese Facebook). September 6, 2009. Available at:

http://www.kaixin001.com/repaste/7212792 546892905.html?stat=xh Accessed on May 12, 2013.

Warnecke, Tonia. "Entrepreneurship and Gender: An Institutional Perspective." Journal of Economic Issues 42, 2 (2013): 455-463.

Weingast, Barry. "The Economic Role of Political Institutions: Market-Preserving Federalism and Economic Development." Journal of Law, Economics, \& Organization 11, (1995): 1-31. Wilhelm, Ian. "Duke's China Plan Sparks Doubt on Campus." The Chronicle of Higher Education May 25, 2011. Available at http://chronicle.com. Accessed August 18, 2013. Williamson, Oliver. The economic institutions of capitalism, New York, NY. Free Press. 1985. Wolfgang Franke. The Reform and Abolition of the Traditional China Examination System. Cambridge MA: East Asian Research Center. 1968. 
Wong, Frank. "Education and Work in China: What Can We Learn from China's Experiences?" Change: The Magazine of Higher Learning 12, 8 (1980) 24-58. 1980.

World Values Survey. Accessed online at http://www.worldvaluessurvey.org/WVSContents.jsp. 2015.

Yajun, Jiang. “English as a Chinese Language." English Today 19, 2 (2003) 3-8.

Yue X.M., Terry Sicular, Shi Li and B.A. Gustaffson. "Explaining Incomes and Inequality in China." In Inequality and Public Policy in China, edited by B. A. Gustafsson, Li Shi and Terry Sicular, pp. 88-117. Cambridge, UK: Cambridge University Press, 2008.

Zhang, Peter. "Inside Story: Exposing English Training Centers transl." 2012. Available at: http://liuxiaofu.diandian.com/post/2012-05-14/18845272 Accessed on May 142013.

Zheng, Amy. "National Education Levels in China."2012. Available at http://www.uschina.usc.edu/. Accessed August 14, 2013.

Zhou, Hao. "Senior Year (Gao San)." 2005. Available at http://www.asianoffbeat.com/post/Documentary-about-Gaokao:-Senior-Year-video2061. Accessed May 15, 2013. 